\title{
Temporal - Spatial Characteristics of Sediment Yield of Slope-Gully Sys- tem based on Artificial Rainfall Simulation
}

\author{
C.X. YANG ${ }^{1}$, D.M. FAN ${ }^{2}$ \& J.X. WANG ${ }^{2}$ \\ ${ }^{1}$ Institute of Yellow River Hydraulic Research, Key Laboratory of Yellow River Sediment Research \\ of Ministry of Water Resources, Zhengzhou,China,450003 \\ ${ }^{2}$ North China University of Water Resources and Electric Power. Department of Resource and \\ Environment, Zhengzhou,China, 450045
}

KEYWORD: Slope-Gully System, Erosion and Sediment Yield, Temporal - Spatial Distribution, Artificial Rainfall Simulation.

ABSTRACT: Slope-gully system is the basic unit not only to study erosion and sediment yield but also to configure the measures in watershed. Based on the rainfall simulation experiment, the temporal - spatial distribution characteristics of sediment yield were studied in slope gully system. The result showed that the most serious erosion occurred as the upper part of gully and the bottom of the slope, the next is the middle of the slope and gully. The results will have some valuable to the production practice.

\section{Introduction}

Slope-gully system was defined based on the distribution which the runoff collected was along the continuous distribution terrain of small watershed. It was the geomorphic units which formed with the vertical structure from top to bottom of the watershed. That was the basic unit to study sediment yield and measures configured in watershed. The slope and gully surface erosion feature was conducted by the methods of tracer ${ }^{[1,2]}$ or runoff scouring simulation ${ }^{[2,3]}$ or artificial rainfall simulation ${ }^{[4]}$ or image interpretation ${ }^{[5]}$ or field investigation ${ }^{[6]}$, and the study results including the vertical zonation characteristics of erosion $^{[6]}$, Clarified the hydrodynamic characteristics ${ }^{[3,4]}$, qualitative represented the evolution characteristics and the erosion process ${ }^{[7,8]}$, Meanwhile, achieved some quantitative conclusions of erosion contribution rate of slope gully system ${ }^{[1,9]}$. However, It was less on spatial distribution characteristics of erosion development about Slope-gully system, It was important for the measures taking out to recognize the erosion characteristic in different development stages in slopegully system.

\section{Materials and Methods}

\section{Experimental Design}

The artificial rainfall simulation was carried out with automation equipment which was belonged to rainfall experiment hall. The rainfall nozzle was 12 meters from the ground, and the rain dripping speed can similar to the natural state.

Slope-gully system simulation was done by the steel box-type device in the hall, The device was composite with two parts of slope and gully, and the slope and gully gradient respectively was $20^{\circ}$ and $35^{\circ}$, And filled with Zhengzhou Mangshan loess, and to control the density in the range of 1.20$1.25 \mathrm{~g} / \mathrm{cm}^{3}$. According to the observation and analysis, the slope-gully system were broken up into P$1 \mathrm{~m} \sim \mathrm{P}-5 \mathrm{~m}$ and G-1m $\sim$ G-5m (showed in Figure 1).

Simulated with the typical rainfall which occurred on the Loess Plateau, Select the rainfall intensity was $1.42 \mathrm{~mm} / \mathrm{min}$, and the rainfall lasted for 60 minutes. 


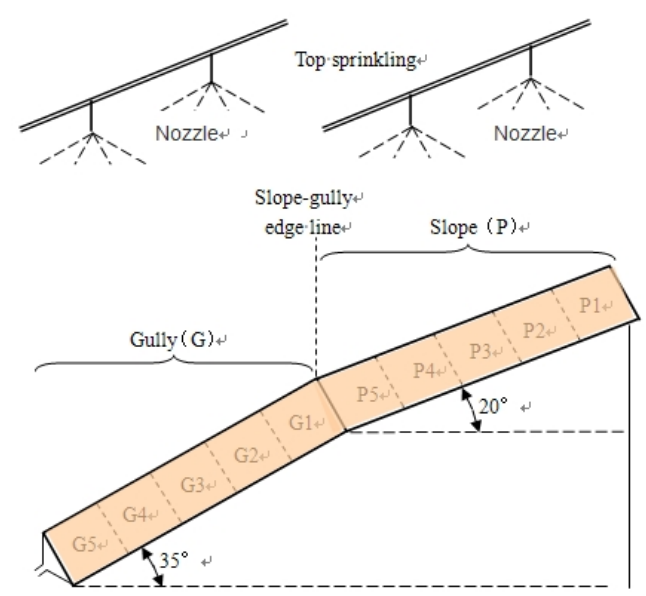

\section{Experimental observation}

Figure 1 Slope-gully system model and rainfall simulation system diagram

During the experiment, Muddy water samples was get every $2 \mathrm{~min}$, and including to extract the samples from different spatial positions with $100 \mathrm{ml}$ syringes, Take the method of water and sediment density conversion to calculate the runoff and sediment yield and other parameters; At the same time, recording the surface erosion evolution by photographed every $2-4 \mathrm{~min}$.

\section{Results and analysis}

\section{Runoff and Sediment Yield Process Analysis}

For the entire slope-gully system, with the increase of rainfall, runoff and sediment yield process have experienced 3 stages of "increase - volatility stable - increase" phase. The first phase of the increasing of runoff and sediment yield occurred within 20 minutes, the volatility stable phase occurred probably between 20 to 40 minutes, and the last increase phase occurred after 40 minutes later, it was showed in Figure 2. The process of sediment content and erosion rate were consistent with runoff and sediment yield process (shown in Figure 3).

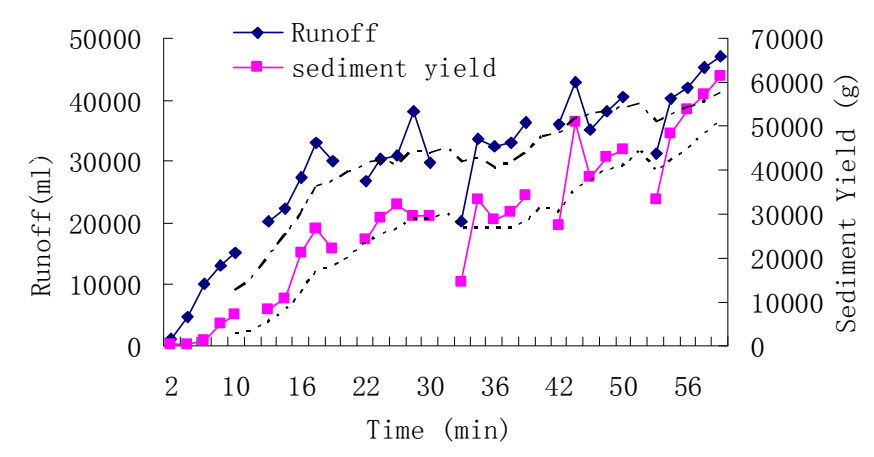

Figure 2 Runoff and sediment yield processes

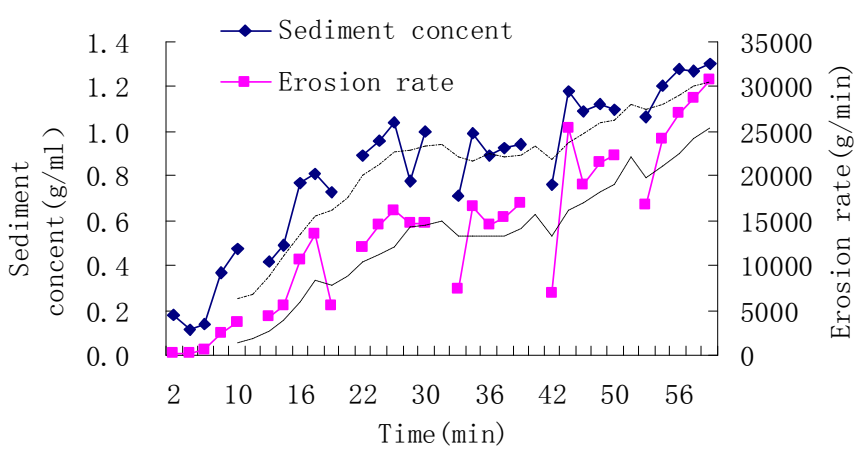

Figure 3 Sediment content and erosion rate process

\section{Spatial and temporal distribution of sediment content along the slope and gully}

Which sediment contents of the runoff at different positions was the performance of erosion distribution. According to the experiment observation, the surface erosion process of slope- gully system can 
be divided into surface erosion, rill erosion and gully erosion stage, the sediment content of various stages shown in Figure 4. With rainfall continuous, the rainfall energy was increasing, and at the same time, the energy was also increasing from top to bottom in the slope -gully system. It was showed in the data line that the stage of surface erosion was lowest, followed by rill stage, and the highest was gully erosion stage. Especially after the rill appeared, the emergence of sediment carrying capacity of runoff was significantly higher than surface erosion stage. At the spatial distribution, Gully runoff sediment content was significantly higher than which slope runoff sediment content, especially at the second section $(\mathrm{G}-2 \mathrm{~m})$. This phenomenon was related to the surface morphological development and evolution of the slope and gully system.

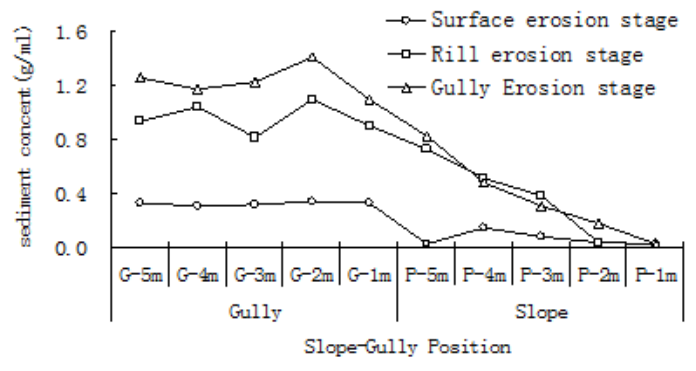

Figure 4 Temporal and spatial distribution of sediment conten

\section{Spatial - temporal distribution of denudation area}

Captured erosion picture of slope-gully system using the camera, then extracted the parameters including the length and width of each 1 meter section using a ruler of $50 \mathrm{~cm}$ as reference, then the denudation area were calculated and analyzed (shown in Figure 5). The size of denudation area was a reaction of the erosion degree in slope-gully system, Figure 5 showed that the earliest section which appeared rill erosion were G-1m section and G-3m section of gully. And both occurred within the first 10 min of the rainfall experiments, The secondly was the middle slope (P-3m, P-4m) sections, The fastest of the erosion development was the section which located at the top of gully (G-1m section ), The process observation showed that, the head of the G-1m section extending and stretching forward through the section of P-5m which located at the bottom of the slope, And all this phenomenon happened in the transition zone of slope - gully system was within $45 \mathrm{~min}$; Until the end of the rainfall experiments, more than $80 \%$ of the original surface has been denuded at the transition zone(P-5m\& G-1m sections), Secondly, the middle section of gully（G-3m) and the lower part of the slope (P-4m section) was also very serious.



Figure 5 Spatial - temporal distribution of denudation area

\section{Spatial - temporal distribution of rainfall energy}

Rainfall energy was increasing from the top to the bottom of the slope-gully system, Defined the rainfall energy (total flow) was the product of three parameters such as rainfall intensity, rainfall duration and water catchment's area. Draw the correlation between rainfall energy and denudation area, (shown in Figure 6). Compared with other sections, G-1m section appeared rill erosion at the smal- 
lest runoff, and the denudation area increased dramatically with the rainfall energy, Followed by the lower of the slope(P-4m\& P-3m sections), and reached a stable stage at the rainfall energy of 200L; From the rate of denudation area increasing trend with rainfall energy, The fastest expansion of denudation area was appeared at the upper gully (G-1m section) and the bottom of the slope (P-5m section), and reached covering the whole sections when the rainfall energy reached the range of 400-500L.

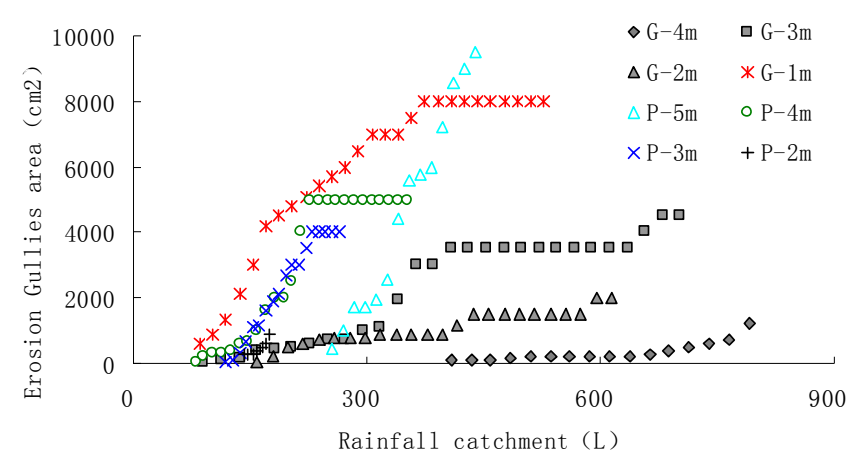

Figure 6 Correlation between rainfall energy and denudation area

\section{Conclusions}

Based on the rainfall simulation of the slope - gully system under the rainfall intensity of 1.42 $\mathrm{mm} / \mathrm{min}$ conditions, Get the following conclusions:

(1) The first 20 minutes of the rainfall showed a surface erosion phase and accompany with a rapid increase of runoff and sediment yield in the slope- gully system, The next 20 minutes belongs rill erosion phase, runoff and sediment yield showed a fluctuating steady stage, The last erosion stage was gully erosion stage, and with the phenomenon of landslide and gully expand obviously, and runoff and sediment yield increase rapidly.

(2) Erosion was likely to occur at the transition region of slope - gully system, and also took place at the zone of slope length 3 meters. Approximately, please pay attention to the prevention measures in the production practice.

\section{Acknowledgement}

This research was supported by the National Key Research Development Program of China(Grant No. 2011CB403303). And the central level scientific research institutes for basic R \& D special business(No.HKY-JBYW-2014-08).

\section{References}

[1] Li Mian, Yang Jian-feng, Hou Jian-cai, et al. Sediment deposition process for a silt dam in a small watershed in Loess Hilly Region[J].Transactions of the CSAE, 2008,24(2):64-69. (in Chinese with English abstract)

[2] Wei Xia, Li Xungui, Li Zhanbin, et al. Simulation experiments on source of eroded sediment from slope-gully systems in Loess Plateau[J]. Transactions of the CSAE, 2009, 25(11): 91-96. (in Chinese with English abstract)

[3] Li Mian, Yao Wen-yi,Chen Jiang-nan et al. Experimental study on runoff resistance of hilly slopegullied surface with grass coverage[J].Journal of Hydraulic Engineering,2007,38(1):112-119. (in Chinese with English abstract) 
[4] Xiao Pei-qing, Zheng Fen-li, Yao Wen-yi.Flow pattern and hydraulic parameter characteristics in hillslope-gullyslope system[J].Advances in Water Science, 2009,20(2):236-240. (in Chinese with English abstract)

[5] T.X. Zhu. Gully and tunnel erosion in the hilly Loess Plateau region China[J].Geomorphology, 2012,Vol.153-154:144-155..

[6] Liu Yuan-bao,Zhu Xian-mo,Zhou Pei-hua,et al.A Study on the Vertical Zoning of Soil Erosion in the Loess Plateau[J]. Memoir of Northwestern Institute of Soil and Water Conservation Academia Sinica, 1988(7) :5-8. (in Chinese with English abstract)

[7] Wang Wen-long, Lei A-lin, Li Zhan-bin et al.Spatial distribution of runoff and sediment in the vertical belts of soil erosion chain in loess region of hilly and gully[J]. Advances in Water Scienc, 2004,1(1):24-28. (in Chinese with English abstract)

[8] Xiao Pei-qing, Zheng Fen-li and Yao Wen-yi. Study on the sediment yield and coupling mechanism of slope-gully system[J]. Journal of Sediment Research, 2007(2):30-35. (in Chinese with English abstract)

[9] Chen Hao.Relationship between Erosion and Sediment Yield in Drainage Basins of Loess GullyHilly Areas[J]. Acta Geographica Sinica, 2000,55(3):354-363. (in Chinese with English abstract). 